\title{
META-ANALISIS PENGGUNAAN VIDEO YOUTUBE DALAM PEMBELAJARAN DI ERA NEW NORMAL PADA SISWA SEKOLAH DASAR
}

\author{
Irmatun Nadhifah ${ }^{1}$, Meirza Nanda Faradita ${ }^{2}$, Fitroh Setyo Putro Pribowo 3 \\ 1,2,3 Pendidikan Guru Sekolah Dasar Universitas Muhammadiyah Surabaya \\ E-mail: 1)Innadhifah8@gmail.com, 2) meirzananda@fkip.um- \\ surabava.ac.id,3) ${ }_{\text {fitrohsetvo@fkip.um-surabava.ac.id }}$
}

\begin{abstract}
ABSTRAK
Penyelenggaraan pendidikan pada masa pandemi ini harus dilakukan secara daring atau belajar dari rumah. Adapun sarana yang digunakan sebagai salah satu media pembelajaran yang sesuai dan membantu belajar siswa belajar dari rumah adalah video pembelajaran melalui youtube. Berdasarkan kondisi yang terjadi selama pandemi serta kajian dari beberapa teori di atas maka tujuan penelitian ini adalah menganalisis penggunaan video youtube dalam pembelajaran jenjang Sekolah Dasar dan mengetahui adanya peningkatan hasil belajar serta motivasi belajar siswa yang diperoleh pada saat menggunakan video youtube dalam pembelajaran. Metode penelitian yang digunakan adalah jenis penelitian kualitatif dengan menggunakan metode meta-analisis untuk menganalisis hasil penelitian yang relevan. Pengumpulan data yang diperoleh dalam penelitian ini dilakukan dengan cara menelusuri jurnal yang tersedia di media elektronik (internet) yang sesuai dengan judul penelitian. Berdasarkan hasil analisis data yang telah tersaji, diketahui bahwa penggunaan youtube dapat meningkatkan hasil belajar dan motivasi belajar siswa. Dibuktikan dengan hasil analisis 10 jurnal, 5 jurnal dengan rata - rata nilai hasil belajar sebesar 83,59 dan 5 jurnal lainnya menunjukkan peningkatan motivasi belajar semakin baik. Berdasarkan hasil penelitian ini, maka dapat dikemukakan saran dari penulis bahwa guru dapat menggunakan media video youtube sebagai salah satu media yang bertujuan untuk meningkatkan hasil belajar dan motovasi belajar siswa.
\end{abstract}

\section{Kata kunci: Video Youtube, Pembelajaran Era New Normal}

\begin{abstract}
The implementation of education during this pandemic must be done online or learn from home. The means used as one of the appropriate learning media and helping students learn from home are learning videos via YouTube. Based on the conditions that occurred during the pandemic and the study of some of the above theories, the aim of this study was to analyze the use of YouTube videos in elementary school level learning and to find out an increase in learning outcomes and student learning motivation obtained when using YouTube videos in learning. The research method used is a type of qualitative research using meta-analysis methods to analyze relevant research results. Data collection obtained in this study was carried out by browsing journals available in
\end{abstract}


electronic media (internet) in accordance with the research title. Based on the results of data analysis that have been presented, it is known that the use of YouTube can improve student learning outcomes and learning motivation. Evidenced by the results of the analysis of 10 journals, 5 journals with an average value of learning outcomes of 83.59 and 5 other journals showed an increase in learning motivation is getting better. Based on the results of this study, it can be suggested that the teacher can use the YouTube video media as a medium that aims to improve learning outcomes and student learning motivation.

\section{Keywords: Youtube Videos, New Normal Learning}

\section{PENDAHULUAN}

Pada tahun ini,seluruh negeri belahan dunia menghadapi kondisi pandemi Covid-19,termasuk di negara kita Indonesia. Menurut data World Health Organization (WHO) sebanyak 213 negara telah terjangkit Covid-19. Covid-19 merupakan penyakit menular, yang berarti dapat menyebar, baik secara langsung maupun tidak langsung, dari satu orang ke orang lain. Kondisi ini menyerang sistem pernafasan seperti hidung, tenggorokan, dan paru-paru. Rumitnya penanganan wabah membuat pemerintah menerapkan kebijakan ketat untuk memutus mata rantai penyebaran Covid-19. Salah satu cara untuk memutus mata rantai penyebaran Covid-19 adalah dengan melakukan pembatasan interaksi masyarakat yang kita kenal dengan istilah physical distancing (menjaga jarak fisik). (Mustakim;2020)

Demikian juga dalam proses penyelenggaraan pendidikan, keputusan pemerintah Indonesia Sesuai Surat Edaran Nomor 15 tahun 2020 tentang pedoman penyelenggaraan belajar dari rumah dalam masa darurat penyebaran Covid-19 adalah sebagai upaya pencegahan penularan virus covid-19. Salah satu metode yang digunakan dalam pembelajaran dari rumah adalah pembelajaran secara daring. Pembelajaran daring merupakan sistem pembelajaran yang dapat dilakukan dengan tidak langsung, tetapi menggunakan media yang dapat membantu pembelajaran jarak jauh. Tujuan dari pembelajaran daring adalah memberikan pembelajaran bermutu dalam jaringan yang bersifat masif dan terbuka untuk menjangkau peminat ruang belajar agar lebih banyak dan lebih luas (Sofyana \& Abdul, 2019:82 ). Selama pelaksanaan pembelajaran jarak jauh, guru perlu memilih media pembelajaran yang tepat, sehingga dapat menyampaikan materi dengan baik. Media pembelajaran adalah alat bantu apa saja yang dapat dijadikan sebagai penyalur pesan agar tercapai tujuan pembelajaran.(Djamarah 
dan Zain,2010:121)

Hal ini tentu peranan guru dalam dunia pendidikan sangatlah penting untuk mencerdaskan bangsa. Guru harus aktif, kreatif, dan inovatif dalam menciptakan pembelajaran yang menarik dan menyenangkan. Pemanfaatan IT sebagai media pembelajaran merupakan salah satu perwujudaan dari peraturan pendidikan dan kebudayaan di indonesia No 65 tahun 2013 tentang standar proses pendidikan dasar dan menengah point 13 yang mengemukakan pemanfaatan IT dalam pembelajaran dapat meningkatkan efektif dan efesiensi pembelajaran. Sebagai upaya untuk meningkatkan kompetensi tersebut, maka guru-guru harus meningkatkan profesionalismenya dengan belajar IT.

Azhar (2011: 49) menyatakan bahwa video merupakan gambar - gambar dalam frame, dimana frame demi frame diproyeksikan melalui lensa proyektor secara mekanis sehingga pada layar terlihat gambar hidup. Video merupakan salah satu jenis media audio-visual dan dapat menggambarkan suatu obyek bergerak berasama-sama dengan suara yang alami dan sesuai. Video juga dapat menyajikan informasi,menjelaskan konsep, memaparkan proses, mengajarkan ketrampilan, menyingkat atau memperpanjang waktu dan mempengaruhi sikap. Menurut KBBI (2020).

Video adalah bagian yang memancarkan gambar pada pesawat televisi,atau rekaman gambar hidup atau program televisi untuk ditayangkan lewat pesawat televisi. Jadi, video merupakan tayangan gambar bergerak yang disertai dengan suara. Berdasarkan beberapa pengertian tersebut, dapat disimpulkan bahwa video merupakan salah satu jenis media audio-visual dan dapat menggambarkan suatu objek yang bergerak bersama-sama dengan suara alamiah atau suara yang sesuai.

Oleh karena itu video ini digunakan sebagai salah satu media pembelajaran yang sesuai dan membantu belajar siswa selama belajar dari rumah,seperti video pembelajaran di youtube. Menurut Burke,Synder, \& Rager (2009) youtube adalah salah satu situs yang populer saat ini. Berdasarkan sebuah survey, kurang lebih 100.000 lebih video ditonton setiap harinya di youtube.setiap bulannya Youtube dikunjungi 20 juta penonton dengan mayoritas kisaran usia 12-17 tahun. Berdasarkan data tersebut youtube bisa menjadi sumber belajar bagi generasi digital saat ini. Youtube dapat meningkatkan minat dan gaya belajar peserta didik. Youtube juga menawarkan pengalaman pembelajaran dengan teknologi yang baru yang berguna saat mereka lulus. Youtube 
dapat memberikan siswa maupun guru kebebasan dalam berekspresi, berkolaborasi di dalam dunia Kependidikan, serta dapat mendapatkan pengalaman berharga dalam meningkatkan kapabilitas mereka (Wigati,Rahmawati dan Widodo,2014;Rahim Almoswaiand Rashid,2017; Saputra and Fatimah, 2018).

Hal ini akan menjadi pengalaman yang berharga,karena guru akan lebih dekat dengan IT. Menurut Budiargo (2015:47) Youtube adalah video online dan yang utama dari kegunaan situs ini adalah sebagai media untuk mencari, melihat, dan berbagi video yang asli ke dan dari segala penjuru dunia melalui situs web. Selain itu Youtube juga bisa menjadi sumber belajar dan media pembelajaran yang dapat memenuhi kebutuhan belajar generasi digital.sumber belajar merupakan suatu sistem yang terdiri dari sekumpulan bahan atau situasi yang diciptakan dengan sengaja agar peserta diidk dapat belajar secara individual ( Warsita, 2008). Oleh karena itu, youtube banyak dikunjungi atau diakses oleh pengguna atau penonton.

Topik ini sangat menarik untuk dikaji, maka diadakan penelitian yang berjudul "Meta-Analisis Penggunaan Video Youtube Dalam Pembelajaran Di Era New Normal Pada Siswa Sekolah Dasar”. Berdasarkan kondisi dan kebutuhan pembelajaran, maka tujuan penelitian ini adalah menganalisis penggunaan video youtube dalam pembelajaran jenjang Sekolah Dasar dan mengetahui adanya peningkatan hasil belajar serta motivasi belajar siswa yang diperoleh pada saat menggunakan video youtube dalam pembelajaran.

\section{METODE PENELITIAN}

Penelitian yang digunakan dalam penelitian ini adalah jenis penelitian kualitatif dengan menggunakan metode meta-analisis untuk menganalisis hasil penelitian yang relevan. Meta analisis sendiri merupakan upaya dalam peneliti merangkum berbagai hasil penelitian secara kuantitatif atau sebagai cara untuk mengananlisis kembali hasil penelitian yang sudah ada (Soetjipto,2016:22). Pengumpulan data yang diperoleh dalam penelitian ini dilakukan dengan cara menelusuri jurnal yang tersedia di media elektronik (internet) yang relevan sesuai dengan judul penelitian.

Hasil penelusuran jurnal di media elektronik (internet) diperoleh beberapa hasil jurnal yang relevan kemudian jurnal tersebut dipilih berdasarkan kriteria yaitu adanya data yang jelas sebelum diberikan treatment dan setelah diberikan treatment atau hasil 
data yang relevan dengan judul penelitian kemudian data yang sudah diperoleh dianalisis. Analisis menggunakan metode pembanding untuk menentukan data selisih sebelum diberikan treatment dan setelah diberikan treatment. Data yang sudah diperoleh dibagi dengan data sebelum diberikan tretment setelah itu dihitung skor untuk mengetahui berapa (\%) peningkatan terhadap hasil belajar.

Adapun rumus mencari nilai rata-ratanya adalah sebagai berikut:

$$
\text { RATA-RATA }=\frac{\text { JUMLAH NILAI }}{\text { BANYAK DATA }}
$$

(Suharsimi Arikunto: 2010)

SELISIH = Nilai Maksimal - Nilai Minimal

https://mamatematika.wordpress.com/2016/10/18/menghitung-selisih-jarak-perbedaan/

\section{HASIL DAN PEMBAHASAN}

Perbandingan nilai sebelum dan sesudah ini dimaksudkan untuk mengetahui manfaat penggunaan youtube dalam pembelajaran. Berdasarkan data jurnal yang telah disertakan dalam penelitian ini, maka data yang telah diperoleh diolah kembali dengan merangkum dari hasil penelitian yang relevan. Selanjutnya data dianalisis secara deskriptif kuantitatif dan kualitatif.

Penelitian meta analisis ini mengikutsertakan hasil penelitian yang relevan dari beberapa penelitian berikut ini:

1. Fuad Amri,Ika Maryani, Purwanto: Peningkatan Hasil Belajar Daring Kelas 3 SD Al Amin Sinar Putih Melalui Penggunaan Media Video PembelajaranYoutube

2. Ratna Herawati,dkk: Peningkatan Hasil Belajar Kognitif Matematika Pada Pembelajaran Daring Kelas II SDN Sleman 5 Melalui Penggunaan Media PembelajaranYoutube

3. Andi Adam: Penggunaan Media Youtube Berseri Dalam Peningkatan Kemampuan Menulis Siswa Di Sekolah Dasar

4. Syafrudin Nugroho: Upaya Penerapan Youtube Dalam Peningkatan Keterampilan Menyimak Unsur CeritaLisan.

5. Muhifbatul Hukama, Laihat, Masrinawatie : Media Audio Visual Dalam 
Pembelajaran IPA Materi Daur Hidup Terhadap Hasil Belajar Siswa Kelas IV SDN 149 Palembang

6. Aisyah Farhatunnisya: Pemanfaatan Video Youtube Dalam Meningkatkan Motivasi Belajar Siswa Insan lentera

7. W.Iwantara,W.Sadia,I.K.Suma:PengaruhPenggunaan Media Video Youtube Dalam Pembelajaran IPA Terhadap Motivasi Belajar dan Pemahaman Konsep Siswa

8. Yusri,dkk: Efektivitas Penggunaan Media Youtube Berbasis Various Approaches Dalam Meningkatkan Motivasi Belajar Bahasa Inggris

9. Abd.Aziz Tata Pangarsa: Implementasi Media Video Youtube Dalam Pembelajaran PPKn Untuk Meningkatkan Motivasi Belajar Siswa Kelas VI MI Miftahul Abror

10. Aang Solahudin Anwar: Penggunaan Media Audi Visual Terhadap Motivasi Siswa Dalam Belajar Senam Kebugaran Jasmani

Dari 10 jurnal yang penulis ambil tersebut, menunjukkan bahwa media youtube dapat digunakan diberbagai macam pelajaran dan pembelajaran apapun. Dalam penenlitian ini, penulis juga ingin mengetahui peningkatan hasil dan motivasi belajar siswa setelah menggunakan youtube sebagai salah satu media pembelajaran. Berikut ini adalah tabel hasil analisis penggunaan video youtube terhadap hasil belajar dan motivasi belajar siswa:

Tabel 1 Hasil Analisis Penggunaan Video Youtube Terhadap Hasil Belajar Siswa Dalam Pembelajaran di SD

\begin{tabular}{|c|c|c|c|c|c|c|c|}
\hline No & Judul & Peneliti dan & Nama & & Analisi & & \\
\hline & & Tahun & & $\overline{\text { Sebelur }}$ & ISetelah & Selisih & \\
\hline 1. & Peningkatan Hasil Belajar & Penelitian & Prosiding & 66,67 & 92,59 & 25,92 & \\
\hline & & Fuad Amri & & & & & \\
\hline & $\begin{array}{l}\text { Kelas } 3 \text { SD Al Amin Sinar } \\
\text { Putih }\end{array}$ & Ika Maryani & Pendidikan & & & & \\
\hline & $\begin{array}{l}\text { Melalui Penggunaan } \\
\text { Media Video }\end{array}$ & $\begin{array}{l}\text { Purwanto } \\
\text { (2020) }\end{array}$ & Profesi Guru & & & & \\
\hline & Pembelajaran Youtube & & & & & & \\
\hline 2. & Peningkatan Hasil Belajar & Ratna & Prosiding & 55,56 & 88,8 & & 33,33 \\
\hline & Kognitif Matematika Pada & Herawati,dkk & Pendidikan & & & & \\
\hline & Pembelajaran Daring & & Profesi Guru & & & & \\
\hline
\end{tabular}


Kelas II

SDN Sleman 5 Melalui

Penggunaan Media

Pembelajaran

Youtube

3. Penggunaan Media

Youtube

Berseri Dalam

Andi Adam

Konfiks:

66,92

78,32

10,4

Peningkatan

(2019)

Jurnal

Bahasa,

Kemampuan Menulis

Siswa Di

Sastradan

Sekolah Dasar

Pengajaran

4. . Upaya Penerapan Youtube Syafrudin

Dalam

Nugroho

Jurnal

73,5

80,55

Peningkatan Keterampilan

Ilmiah

SARASVA

TI

Menyimak Unsur Cerita

Lisan

5. Media Audio Visual

Dalam

Pembelajaran IPA Materi

Daur

Hidup Terhadap Hasil

Belajar

Siswa Kelas IV SDN 149

Muhifbatul Jurnal

Inovasi

70,9

77,6

6,7

Hukama,

$\begin{array}{ll}\text { Laihat, } & \text { Sekolah } \\ & \text { Dasar }\end{array}$

Masrinawatie

(2017)

Palembang

5

Berdasarkan hasil analisis data yang relevan yang telah tersaji di atas, diketahui bahwa penggunaan youtube dapat meningkatkan hasil belajar siswa. Dibuktikan dengan hasil analisis 5 jurnal yang telah ada sebelumnya dengan rata - rata nilai sebelum menggunakan youtube sebesar 66,71 dan setelah menggunakan youtube meningkat menjadi 83,59. 
Tabel 2 Hasil Analisis Penggunaan Video Youtube Terhadap Motivasi Belajar

Siswa Dalam Pembelajaran di SD

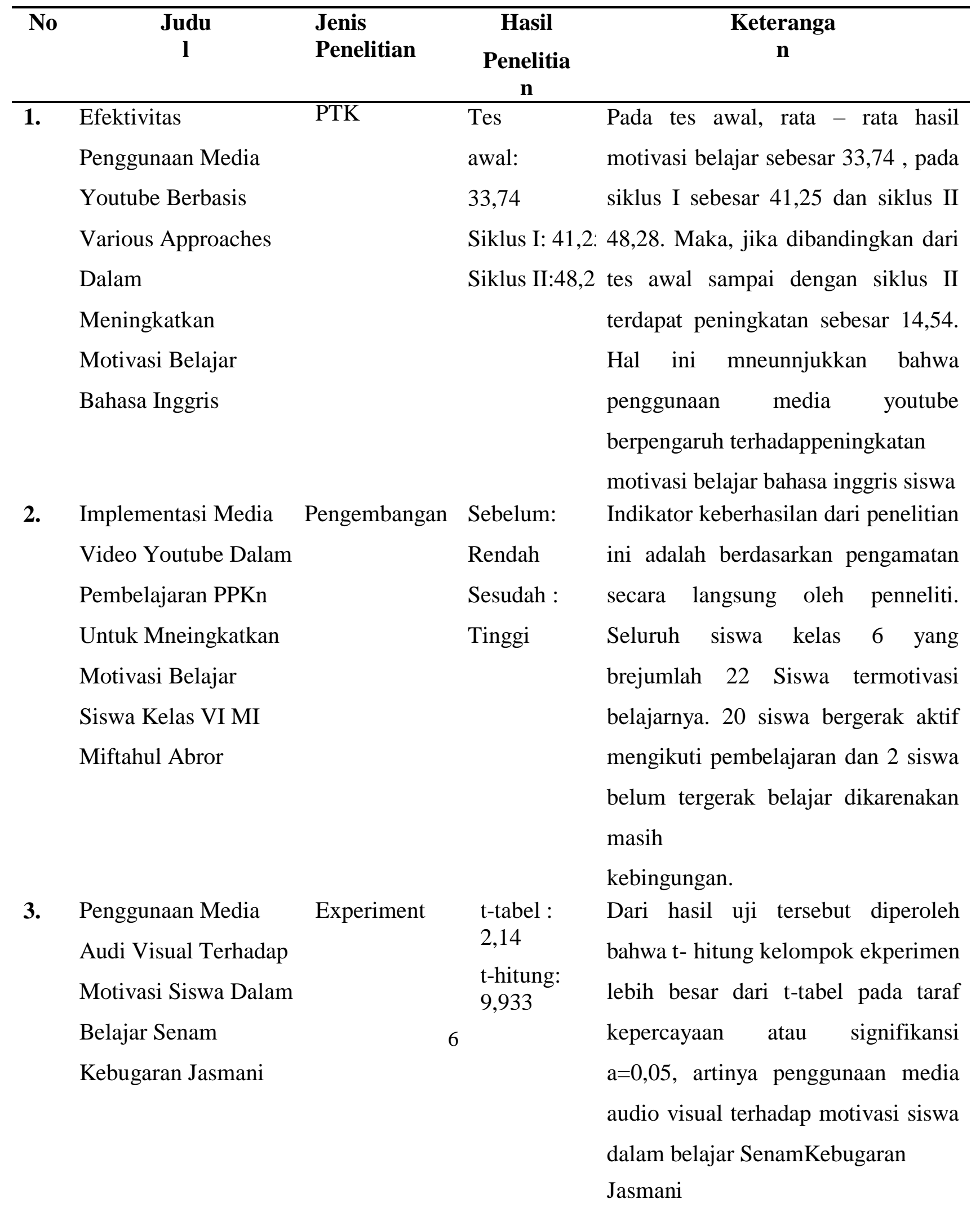




\begin{tabular}{llll} 
4. Pemanfaatan Video & Kualitatif & Sebelu & \multicolumn{2}{l}{ Sebelum adanya penggunaan media } \\
Youtube Dalam & $\mathrm{m}:$ & youtube sebagai media belajar, \\
Meningkatkan & Rendah & motivasi belajara sangan rendah \\
Motivasi & Sesuda & yangmenyebabkan & \\
Belajar Siswa Insan & $\mathrm{h}:$ & suasana kegiatan & belajar \\
lentera & Tinggii & mengajartidak & \\
\hline
\end{tabular}

Berdasarkan hasil analisis data yang relevan yang telah tersaji di atas, diketahui bahwa penggunaan youtube dapat meningkatkan motivasi siswa. Dibuktikan dengan hasil analisis 5 jurnal yang telah ada sebelumnya sebelum menggunakan youtube dalam pembelajaran, motivasi belajar siswa rendah dan mengakibatkan pembelajaran tidak maksimal. Setelah diberikan pembelajaran dengan menggunakan youtube, motivasi belajar siswa meningkat, siswa semakin aktif dan bersemangat dalam pembelajaran.

\section{KESIMPULAN}

Berdasarkan hasil analisis jurnal terkait penggunaan youtube pada tabel 1 mengalami peningkatan sebesar $25 \%$, dan pada tabel 2 motivasi belajar disimpukan mengalami peningkatan pada kegiatan post test. Berdasarkan hal tersebut maka dapat disimpulkan bahwa youtube dapat meningkatkan hasil belajar dan motovasi belajar siswa.

\section{DAFTAR PUSTAKA}

Aang Solahudin Anwar. (2018). Penggunaan Media Audio Visual Terhadap Motivasi Siswa Dalam Belajar Senam Kebugaran Jasmani Jurnal Sekolah Dasar. $\quad$ Vol.1, No.3. Dari http://journal.ubpkarawang.ac.id/index.php/PGSD/article/view/411

Abd.Aziz Tata Pangarsa. (2020). Implementasi Media Video Youtube Dalam Pembelajaran PPKn Untuk Meningkatkan Motivasi Belajar Siswa Kelas VI MI Miftahul Abror. MODELING: Jurnal Program Study PGMI. Vol.7, No.2. Dari https://jurnal.stitnualhikmah.ac.id/index.php/modeling/article/view/663 Aisyah Farhatunnisya. (2020). Pemanfaatan Video Youtube Dalam Meningkatkan Motivasi Belajar Siswa Insan Lentera. Jurnal COMM-EDU. Vol.3, No 2. Dari https://journal.ikipsiliwangi.ac.id/index.php/commedu/article/download/3756/1507

Andi Adam. (2019). Penggunaan Media Youtube Berseri Dalam Peningkatan Kemampuan Menulis Siswa Di Sekolah Dasar. Jurnal Konfiks Bahasa, Sastra dan Pengajaran. Hal. 45-53 Volume 6 Nomor 2. Dari https://journal.unismuh.ac.id/index.php/konfiks/article/view/3992 